\title{
Increased expression of type 2 $3 \alpha$-hydroxysteroid dehydrogenase/type 5 17ß-hydroxysteroid dehydrogenase (AKR1C3) and its relationship with androgen receptor in prostate carcinoma
}

\author{
K-M Fung ${ }^{2,4}$, E N S Samara ${ }^{1}$, C Wong ${ }^{1,4}$, A Metwalli ${ }^{1}, R$ Krlin $^{1}$, B Bane ${ }^{2}$, \\ C Z Liu ${ }^{2}$, J T Yang ${ }^{2}$, J V Pitha ${ }^{2,4}$, D J Cúlkin ${ }^{1,4}$, B P Kropp ${ }^{1}$, T'M Penning ${ }^{3}$ \\ and Hsueh-Kung Lin ${ }^{1,4}$
}

\footnotetext{
${ }^{1}$ Department of Urology, University of Oklahoma Health Sciences Center, 920 Stanton L Young Blvd, WP3150, Oklahoma City, Oklahoma 73104, USA

${ }^{2}$ Department of Pathology, University of Oklahoma Health Sciences Center, Oklahoma City, Oklahoma, USA

${ }^{3}$ Department of Pharmacology, University of Pennsylvania, School of Medicine, Philadelphia, Pennsylvania, USA

${ }^{4}$ Department of Veterans Affairs Medical Center, Oklahoma City, Oklahoma, USA
}

(Requests for offprints should be addressed to H-K Lin at Department of Urology, University of Oklahoma Health Sciences Center; Email: hk-lin@ouhsc.edu)

\begin{abstract}
Type $23 \alpha$-hydroxysteroid dehydrogenase ( $3 \alpha-H S D)$ is a multi-functional enzyme that possesses $3 \alpha-, 17 \beta-$ and $20 \alpha-H S D$, as well as prostaglandin (PG) $F$ synthase activities and catalyzes androgen, estrogen, progestin and PG metabolism. Type $23 \alpha-H S D$ was cloned from human prostate, is a member of the aldo-keto reductase (AKR) superfamily and was named AKR1C3. In androgen target tissues such as the prostate, AKR1C3 catalyzes the conversion of $\Delta^{4}$-androstene3,17-dione to testosterone, $5 \alpha$-dihydrotestosterone to $5 \alpha$-androstane-3 $\alpha, 17 \beta$-diol ( $3 \alpha$-diol), and $3 \alpha$-diol to androsterone. Thus AKR1C3 may regulate the balance of androgens and hence transactivation of the androgen receptor in these tissues. Tissue distribution studies indicate that AKR1C3 transcripts are highly expressed in human prostate. To measure AKR1C3 protein expression and its distribution in the prostate, we raised a monoclonal antibody specifically recognizing AKR1C3. This antibody allowed us to distinguish AKR1C3 from other AKR1C family members in human tissues. Immunoblot analysis showed that this monoclonal antibody binds to one species of protein in primary cultures of prostate epithelial cells and in LNCaP prostate cancer cells. Immunohistochemistry with this antibody on human prostate detected strong nuclear immunoreactivity in normal stromal and smooth muscle cells, perineurial cells, urothelial (transitional) cells, and endothelial cells. Normal prostate epithelial cells were only faintly immunoreactive or negative. Positive immunoreactivity was demonstrated in primary prostatic adenocarcinoma in 9 of 11 cases. Variable increases in immunoreactivity for AKR1C3 was also demonstrated in non-neoplastic changes in the prostate including chronic inflammation, atrophy and urothelial (transitional) cell metaplasia. We conclude that elevated expression of AKR1C3 is highly associated with prostate carcinoma. Although the biological significance of elevated AKR1C3 in prostatic carcinoma is uncertain, AKR1C3 may be responsible for the trophic effects of androgens and/or PGs on prostatic epithelial cells.
\end{abstract}

Endocrine-Related Cancer (2006) 13 169-180 


\section{Introduction}

Androgens are critical for maintaining normal function of the prostate gland and are also trophic factors for the development of human prostate carcinoma (CaP) (Isaacs et al. 1994). The orchestrated expression of androgen-metabolizing enzymes including $5 \alpha$-reductase type $2,17 \beta$-hydroxysteoid dehydrogenase (HSD), $3 \alpha-H S D$ and $3 \beta$-HSD is critical to maintain the balance of different androgen metabolites within the prostate to maintain its normal physiological function. The type $23 \alpha-\mathrm{HSD}$ was cloned from a human prostate cDNA library by us (Lin et al. 1997), was found to belong to the aldo-keto reductase (AKR) superfamily, and was designated AKR1C3. AKR1C3 possesses $3 \alpha$-HSD, $17 \beta$-HSD, 20 $\alpha$-HSD and prostaglandin (PG) $\mathrm{F}$ synthase activities and catalyzes androgen, estrogen, progesterone and PG metabolism (Dufort et al. 1996, Lin et al. 1997, Matsuura et al. 1998, Penning et al. 2001). AKR1C3, therefore, has the capability of regulating ligand access to multiple nuclear receptors including the androgen receptor (AR), estrogen receptor, progesterone receptor and peroxisome proliferator activated receptor gamma $(\operatorname{PPAR} \gamma)$ in endocrine peripheral tissues.

In androgen metabolism, AKR1C3 catalyzes the reductive reaction of $5 \alpha$-dihydrotestosterone $(5 \alpha-$ DHT) to $5 \alpha$-androstane- $3 \alpha, 17 \beta$-diol ( $3 \alpha$-diol) by its $3 \alpha$-HSD activity (Lin et al. 1997) and the conversion of $\Delta^{4}$-androstene-3,17-dione ( $\Delta^{4}$-dione) to testosterone by its $17 \beta$-HSD activity (Labrie et al. 2000a) (Fig. 1). $5 \alpha-$ DHT and testosterone are active androgens in the prostate, and responsible for physiological and pathological development of the gland. It has been assumed that $3 \alpha$-diol has no androgenic effects unless it is first oxidized back to $5 \alpha$-DHT (Jacobi et al. 1978, Mahendroo et al. 1996, Wilson et al. 2003a,b). We recently reported that $3 \alpha$-diol may stimulate prostate cell proliferation through an AR-independent, epidermal growth factor-like pathway(s) (Nunlist et al. 2004, Zimmerman et al. 2004). These results would be consistent with previous reports describing $3 \alpha$-diolinduced prostate enlargement in a castrated dog model

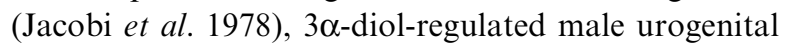
tract development in the fetus of the pouch of female marsupials (Wilson et al. 2003b), and 3 $\alpha$-diol-induced parturition in a mouse model (Mahendroo et al. 1996). AKR1C3, therefore, can be a candidate enzyme in regulating the activation of $\mathrm{AR}$ or growth factor signaling pathways through local accumulation of testosterone, $5 \alpha$-DHT, or $3 \alpha$-diol for prostate growth.

In PG metabolism, AKR1C3 catalyzes the 11keto-reduction of $\mathrm{PGD}_{2}$ to yield the $\mathrm{PGF}_{2 \alpha}$ epimer,
$9 \alpha, 11 \beta-\mathrm{PGF}_{2 \alpha}$, thereby depriving PPAR $\gamma$ of its putative ligand $15 \Delta-\mathrm{PGJ}_{2}$ (Desmond et al. 2003). In normal prostate, epithelial cells do not express PPAR $\gamma$ but in PC-3 prostate cancer cells, which express PPAR $\gamma, 15 \Delta \mathrm{PGJ}_{2}$ is growth inhibitory (Subbarayan et al. 2004). $15 \Delta \mathrm{PGJ}_{2}$ is derived from normal stromal cells and suppresses adjacent tumor growth (Kim et al. 2005). These growth inhibitory properties may be mediated by downregulation of cyclooxygenase (COX)-2 by $15 \Delta \mathrm{PGJ}_{2}$ (Sabichi et al. 2004). In vivo, results with COX-2 inhibitors also show a pronounced inhibitory effect on tumor microvessel density and angiogenesis (Kirschenbaum et al. 2001). In the presence of elevated AKR1C3, $\mathrm{PGD}_{2}$ will be diverted to its pro-proliferative ligand $9 \alpha, 11 \beta-\mathrm{PGF}_{2}$. Thus AKR1C3 may also be intimately involved in controlling proliferative growth and vascular development in the diseased prostate.

Tissue and prostate distribution of AKR1C3 has been investigated. Using an AKR1C3 $3^{\prime}$-UTR as a cDNA probe, transcript expression of AKR1C family members including AKR1C2/AKR1C3 was detected in multiple tissues including prostate (Lin et al. 1997). Expression of these transcripts was also detected in primary cultures of both prostate epithelial and stromal cells with higher levels of transcript expression in epithelial cells (Lin et al. 1997). Semi-quantitative AKR1C isoform-specific RT-PCR confirmed the high expression of AKR1C3 in the prostate (Penning et al. 2000). AKR1C3 has been shown to be expressed in the Leydig cells of the testis as well as prostate basal and luminal epithelial cells using an anti-AKR1C3 polyclonal antibody raised against the C-terminal domain of the protein (Pelletier et al. 1999). Immunoaelectron microscopy shows no association with specific organelles compatible with the cytosolic localization of AKRs (Pelletier et al. 2001) but some nuclear staining was noted.

To further study AKR1C3 protein expression in the prostate, we developed and characterized a mouse anti-human $3 \alpha$-HSD monoclonal antibody (mAb; clone NP6G6.A6). This $\mathrm{mAb}$ is monospecific against AKR1C3 (Lin et al. 2004) and does not cross-react with AKR1C1, AKR1C2 or AKR1C4. In this report, we extend our investigation of AKR1C3 distribution in $\mathrm{CaP}$ tissues. High levels of immunoreactivity were observed in all endothelial cells in the prostate with staining in some stromal cells. In contrast to low immunoreactivity in normal prostate epithelium, strong positive staining was detected in the epithelium of the majority of $\mathrm{CaP}$ cases along with other prostate pathologies. Elevated AKR1C3 expression in human $\mathrm{CaP}$ may result in an imbalance of androgen 

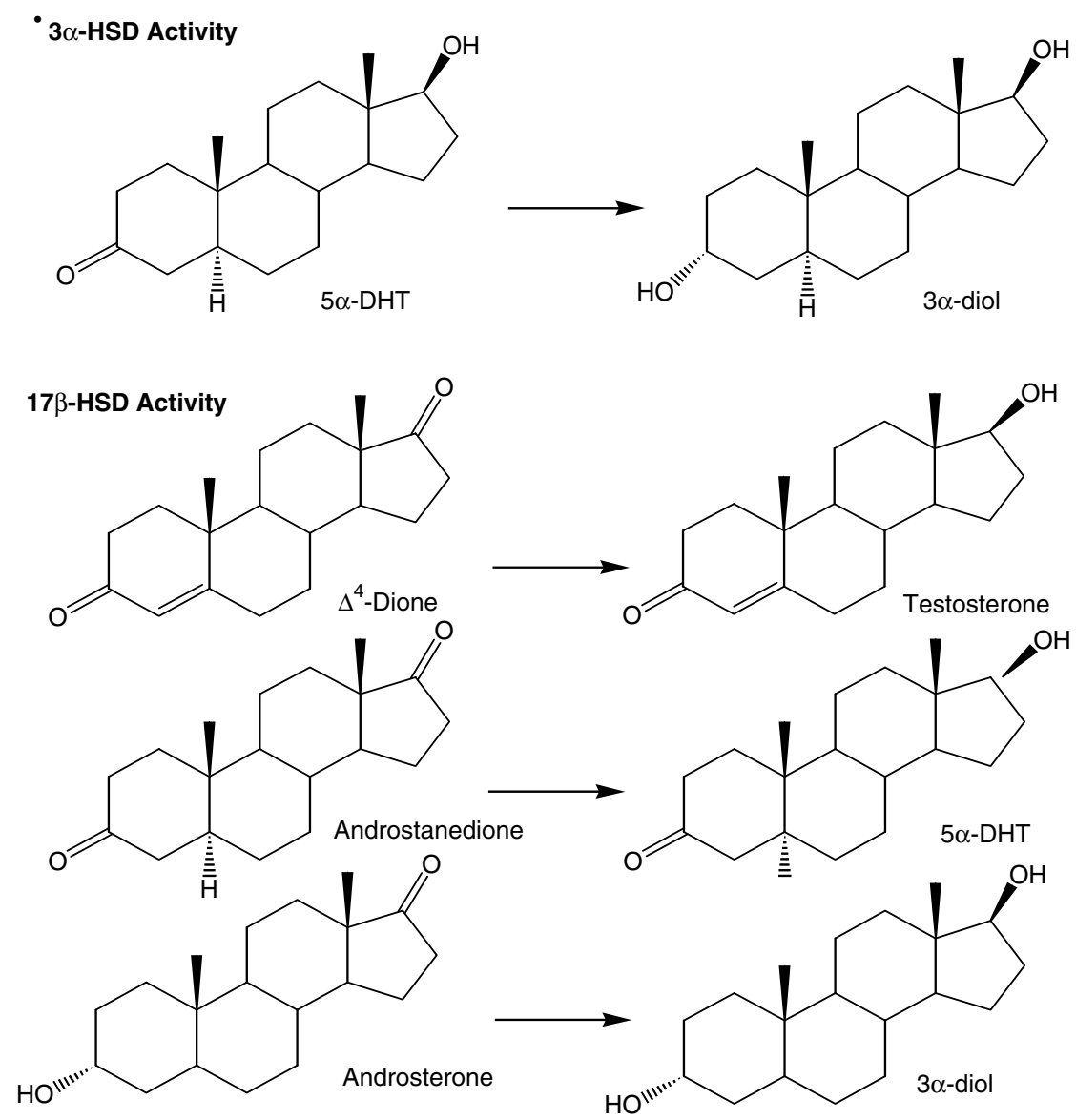

11-Ketoprostaglandin Reductase Activity<smiles>[R]C=CC[C@H]1[C@H](O)CC(=O)[C@@H]1/C=C/[C@@H]([R20])O</smiles>

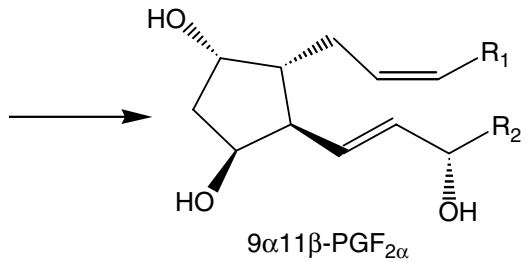

Figure 1 Summary of AKR1C3-mediated nuclear receptor ligand metabolism. AKR1C3 has $3 \alpha-$ and 17 $\beta$-HSD, and 11-ketoprostaglandin reductase activities.

metabolism in the prostate, which may lead to abnormal prostate growth through de-regulated trans-activation of nuclear receptors (AR and PPAR $\gamma$ ).

\section{Materials and methods}

\section{Reagents}

Mouse anti-human AR mAb was acquired from Vector Laboratories (Burlingame, CA, USA). Mouse anti-human type $23 \alpha$-HSD (AKR1C3) mAb was prepared at the Cell Center, University of Pennsylvania
School of Medicine as previously described using the full-length recombinant AKR1C3 protein as the antigen (Lin et al. 2004). Kenneth's HY, RPMI 1640, keratinocyte serum-free medium (K-SFM), and fetal bovine serum (FBS) were purchased from Invitrogen (Carlsbad, CA, USA), and ORIGEN hybridoma cloning factor was obtained from IGN International (Gaithersburg, MD, USA). Charcoal/dextran-treated FBS was purchased from HyClone (Logan, UT, USA). Hematoxylin and eosin were purchased from Sigma (St Louis, MO, USA). Biotinylated goat anti-mouse 
secondary antibody, horseradish peroxidase (HRP)conjugated streptavidin, and diaminobenzidine tetrahydrochloride (DAB) $-\mathrm{H}_{2} \mathrm{O}_{2}$ substrate were obtained from BioGenex (San Ramon, CA, USA).

\section{Cell Culture}

Human prostate LNCaP cells were obtained from ATCC and maintained in growth medium consisting of RPMI 1640 medium supplemented with $10 \%$ FBS, 100 units $/ \mathrm{ml}$ penicillin and $100 \mu \mathrm{g} / \mathrm{ml}$ streptomycin (Invitrogen) in a humidified cell incubator at $37^{\circ} \mathrm{C}$ in $5 \% \mathrm{CO}_{2}$. Primary cultures of prostate cells were prepared from prostate following surgical radical prostatectomy as described by Lang et al. (2001). Primary cultures of prostate cells were established and maintained in K-SFM supplemented with $1 \%$ charcoal/dextran-treated FBS.

The hybridoma line that produces anti-human AKR1C3 mAb was maintained in hybridoma growth media consisting of Kenneth's HY, 20\% FBS, 2\% hybridoma cloning factor, $4 \mathrm{mM}$ L-glutamine and $1 \%$ OPI Media Supplement (Sigma).

\section{Western blot analysis}

Cellular proteins were prepared from $\mathrm{LNCaP}$ cells and from primary cultures of prostate epithelial cells in a modified RIPA buffer (50 mM Tris- $\mathrm{HCl}(\mathrm{pH} 7.4)$, $1 \%$ NP-40, $0.25 \%$ sodium deoxycholate, $150 \mathrm{mM}$ $\mathrm{NaCl}, 1 \mathrm{mM}$ EDTA and $2 \mathrm{mM}$ phenylmethylsulfonyl fluoride). Total soluble proteins $(30 \mu \mathrm{g})$ were electrophoresed on a $12 \%$ Tris- $\mathrm{HCl}$ gel (Bio-Rad). Proteins were transferred onto polyvinylidene difluoride (PVDF) membranes (Bio-Rad). The membranes were blocked with $5 \%$ non-fat dry milk (Bio-Rad) in Trisbuffered saline containing 1\% Tween 20. Antigens were detected by incubating with mouse anti-human AKR1C3 mAb (1:500) or anti- $\beta$-actin mAb (1:5000; Sigma) at room temperature for $2 \mathrm{~h}$ followed by incubation with HRP-conjugated anti-mouse $\operatorname{IgG}$ ( 1 : 125000 ; KPL, Gaithersburg, MD, USA) secondary antibody at room temperature for another $1 \mathrm{~h}$. Immunoreactive protein was then detected using enhanced chemiluminescence reagent (Pierce, Rockford, IL, USA) according to the manufacturer's protocol.

\section{RT-PCR analysis of AKR1C3 mRNA}

Amplification of AKR1C3 and $\beta$-actin mRNA was performed using AKR1C3 isoform-specific primers (Penning et al. 2000) from total RNA isolated from $\mathrm{LNCaP}$ cells and primary cultures of prostate epithelial cells.
Table 1 Summary of age, Gleason score and percentage of AKR1C3-positive cancer cells

\begin{tabular}{cccc}
\hline $\begin{array}{l}\text { Case } \\
\text { No. }\end{array}$ & Age & $\begin{array}{c}\text { Gleason } \\
\text { score }\end{array}$ & $\begin{array}{c}\text { AKR1C3-positive } \\
\text { cancer cells (\%) }\end{array}$ \\
\hline 1 & 68 & $4+3$ & $>75$ \\
2 & 69 & $3+4$ & $>75$ \\
3 & 56 & $3+4$ & $>75$ \\
4 & 68 & $3+3$ & $>75$ \\
5 & 59 & $3+3$ & 50 \\
6 & 64 & $3+4$ & 25 \\
7 & 59 & $3+4$ & 25 \\
8 & 60 & $4+3$ & 25 \\
9 & 56 & $3+3$ & 10 \\
10 & 65 & $3+4$ & 0 \\
11 & 52 & $3+4$ & 0 \\
\hline
\end{tabular}

\section{Human prostate tissues}

Archival formalin-fixed, paraffin-embedded prostate tissue blocks and their associated clinical information were acquired from the Department of Pathology, University of Oklahoma Health Sciences Center in accordance with an approved Institutional Review Board protocol.

All of the prostate glands were obtained through radical prostatectomy. A total of 11 cases of $\mathrm{CaP}$ were used in this study (Table 1). Prostate tissue that was free of carcinoma was obtained from an additional case (radical cystoprostatectomy) and used as a control. The diagnoses were rendered by four pathologists (B B, CZ L, J T Y and K M F) and reviewed by one of the pathologists (KMF). Semi-serial paraffin sections were cut at $4-6 \mu \mathrm{m}$, dried at $55^{\circ} \mathrm{C}$ overnight, and stored at $-20^{\circ} \mathrm{C}$ until use. Slides were deparaffinized with xylene and rehydrated in graded ethanol before use as previously described (Lin et al. 2004).

\section{Hematoxylin-eosin stain}

Deparaffinized and rehydrated slides were stained in hematoxylin and blued in lithium carbonate solution. The slides were then washed, stained with eosin, washed, dehydrated and sealed with Permount Mounting Media (Sigma).

\section{Immunohistochemistry (IHC) of human prostate tissue sections}

IHC was performed with a three-step, peroxidasemediated mechanism as previously described (Fung et al. 1995). Briefly, deparaffinized and rehydrated tissue sections were incubated with $0.5 \% \quad \mathrm{H}_{2} \mathrm{O}_{2}$ in methanol for $10 \mathrm{~min}$ to block endogenous peroxidase 
activity. Antigen retrieval was performed by heating the slides in $10 \mathrm{mM}$ citric acid buffer (pH 6.0) in a microwave oven at $1200 \mathrm{~W}$ for $20 \mathrm{~min}$. The slides were then washed with $0.1 \mathrm{M}$ Tris- $\mathrm{HCl}$ at $\mathrm{pH} 7.6$ (TRIS) for $5 \mathrm{~min}$ and then incubated with TRIS containing $10 \%$ goat serum to block non-specific binding. Slides were then incubated with AKR1C3 mAb (NP6G6.A6) at a dilution of $1: 200$ of at $4{ }^{\circ} \mathrm{C}$ overnight. After washing with TRIS, the slides were incubated with biotinylated goat anti-mouse secondary antibody in TRIS containing $10 \%$ goat serum at room temperature for $1 \mathrm{~h}$. Following washes with TRIS, HRP-conjugated streptavidin diluted in TRIS containing $10 \%$ goat serum was added to slides and incubated at room temperature for another $40 \mathrm{~min}$. The slides were washed in TRIS for $10 \mathrm{~min}$. A DAB- $\mathrm{H}_{2} \mathrm{O}_{2}$ substrate was added to the slides and incubated at room temperature for $6 \mathrm{~min}$. Slides were then washed with distilled water and counterstained with hematoxylin. Slides were dehydrated and sealed with Permount Mounting Media for visualization.

\section{Scoring of IHC for AKR1C3-positive cancer cells}

The percentage of positively immunoreactive cells with IHC staining was evaluated and graded into five categories: over $75 \%$ positive $(>75 \%), 50 \%$ positive $(50 \%), 25 \%$ positive $(25 \%), 10 \%$ positive $(10 \%)$ and negative $(0 \%)$.

\section{Results}

\section{Detection of AKR1C3 in cultured human prostate cells}

We have previously reported the monospecificity of the mAb (NP6G6.A6) and shown that it only recognizes recombinant AKR1C3 among members of the AKR1C family (Lin et al. 2004). To demonstrate the ability of this antibody to specifically distinguish AKR1C3 from other cellular proteins, Western blot analysis was performed in total cellular lysates prepared from primary cultures of prostate epithelial cells (normal and $\mathrm{CaP}$ ) and from androgen-sensitive human prostate cancer $\mathrm{LNCaP}$ cells. A single protein species with a molecular mass of approximately $37 \mathrm{kDa}$ was detected in these total cellular protein preparations (Fig. 2B). The recognized protein species had the same size as the recombinant AKR1C3 protein (Lin et al. 1997, 2004). To correlate the levels of AKR1C3 protein expression with its transcript expression in the cultured prostate cells, AKR1C3 mRNA was
A

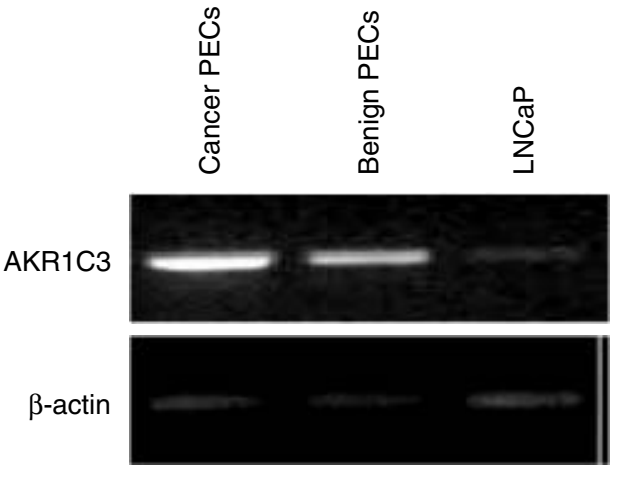

B
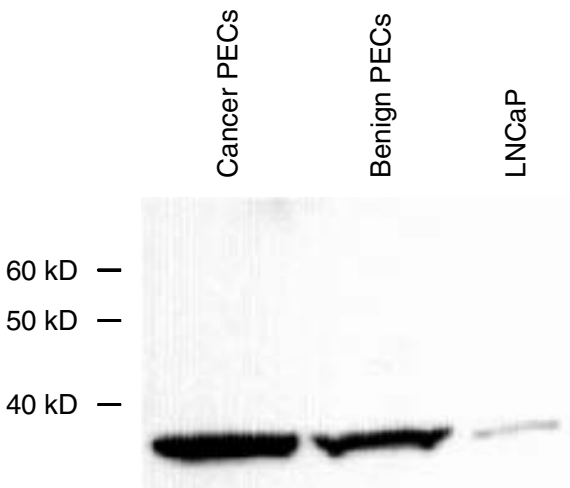

$30 \mathrm{kD}-$

$20 \mathrm{kD}-$

$\beta$-actin -

Figure 2 Comparable levels of AKR1C3 transcript and protein expression in prostate cells. (A) RT-PCR detection of AKR1C3 transcripts. Total RNA was extracted from cultured prostate epithelial cells (PECs) and LNCaP cells and used for reverse transcription. AKR1C3 was amplified using AKR1C3-specific primers. (B) Specificity of anti-AKR1C3 mAb. Total cellular proteins were extracted from cultured prostate cells, electrophoresed on Tris- $\mathrm{HCl}$ gels, and transferred to PVDF membranes. Immunodetection of AKR1C3 protein was performed by incubating with mouse anti-human AKR1C3 mAb (clone NP6G6.A6). The immunoblot analysis shows that the $\mathrm{mAb}$ can only react with one species of proteins prepared from PECs and LNCaP cells.

amplified using our established RT-PCR procedures using the isoform-specific primer sets for AKR1C3 (Penning et al. 2000). The results showed comparable 

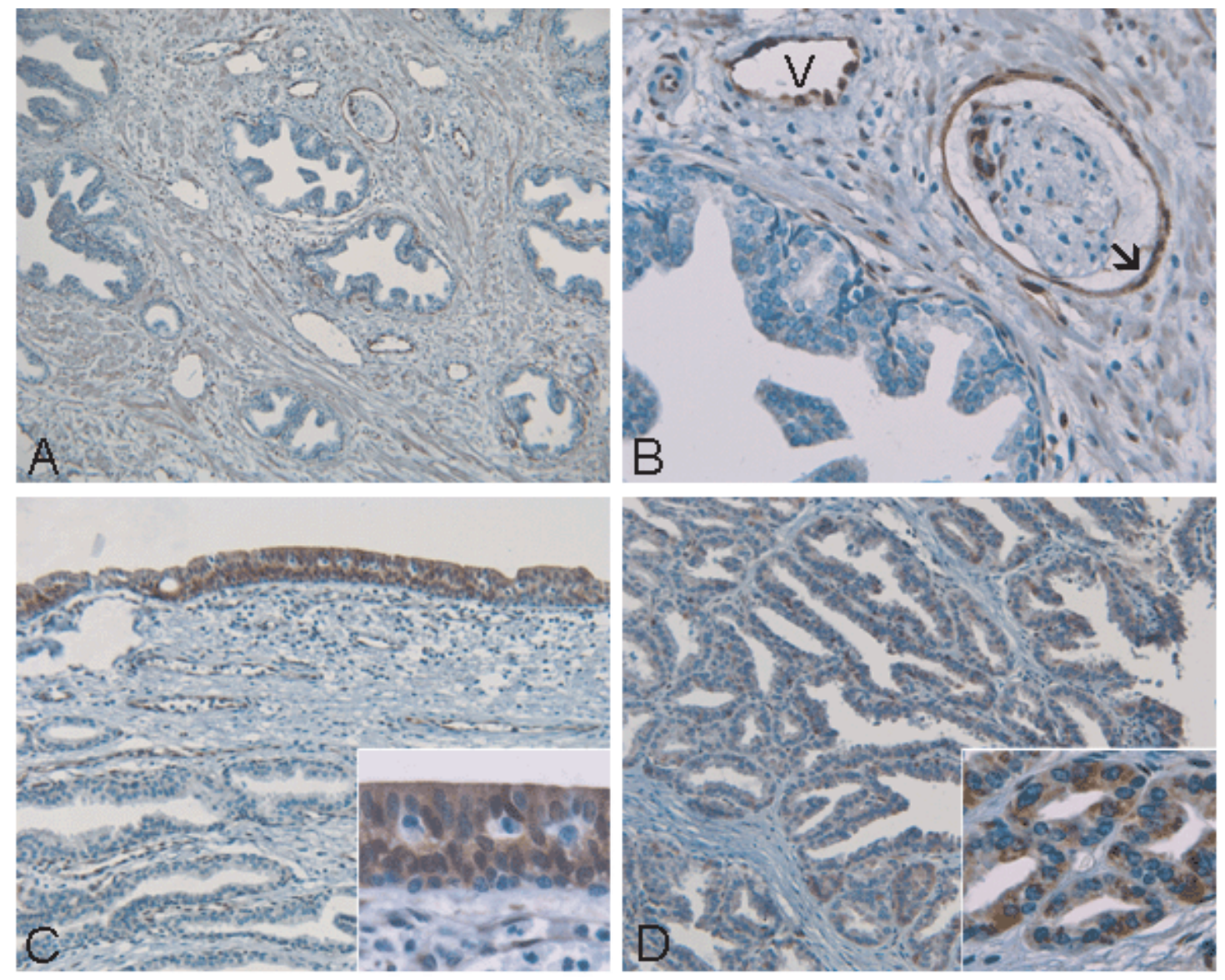

Figure 3 Expression of type $23 \alpha$-HSD (AKR1C3) in normal prostate tissue. (A) and (B) are taken from the same area at lowand high-magnification respectively. Normal prostatic glands are faintly immunoreactive or negative. The stromal cells and smooth muscle cells are variably immunoreactive. Strong cytoplasmic and nuclear immunoreactivity are demonstrated in both endothelial cells in blood vessels (V) and perineurial cells (arrow). (C) is taken from the prostatic urethra in the verumontanum. There are both cytoplasmic and nuclear immunoreactivity (inset). (D) Consistent immunoreactivity is demonstrated in the seminal vesicles with predominantly cytoplasmic immunoreactivity (inset). Original magnification: $(A) \times 10 ;(C)$ and $(D) \times 20$, (B) $\times 40$; insets $\times 60$.

levels of $\mathrm{AKR} 1 \mathrm{C} 3$ protein and transcript expression in these cells (Fig. 2A).

\section{Immunoreactivity of AKR1C3 enzyme protein in normal prostate}

The mAb for AKR1C3 was used for immunohistochemical (IHC) detection of AKR1C3 protein in human prostate tissue. Consistently strongly nuclear and cytoplasmic immunoreactivity of the $\mathrm{mAb}$ was demonstrated in the endothelial cells and perineurial cells (Fig. 3A and B). Variable immunoreactivity was demonstrated in the stromal cells and smooth muscle cells. The glandular epithelial cells were either faintly immunoreactive or non-immunoreactive. Strong nuclear and cytoplasmic immunoreactivity was also demonstrated in urothelial (transitional) cells in the prostatic urethra (Fig. 3C). Predominantly cytoplasmic immunoreactivity was demonstrated in the seminal vesicles (Fig. 3D).

\section{Immunoreactivity of AKR1C3 enzyme protein in CaP}

Positive immunoreactivity was identified in 9 of 11 cases $(81.8 \%)$ of $\mathrm{CaP}$ (Table 1$)$. In general, a variable percentage of carcinomatous cells in these nine $\mathrm{CaP}$ cases was positive. There was no single case in which all the carcinomatous cells were positive but five of the nine cases $(55.6 \%)$ had positive immunoreactivity in over $50 \%$ of the carcinomatous cells (Table 1). Both cytoplasmic and nuclear immunoreactivity were 

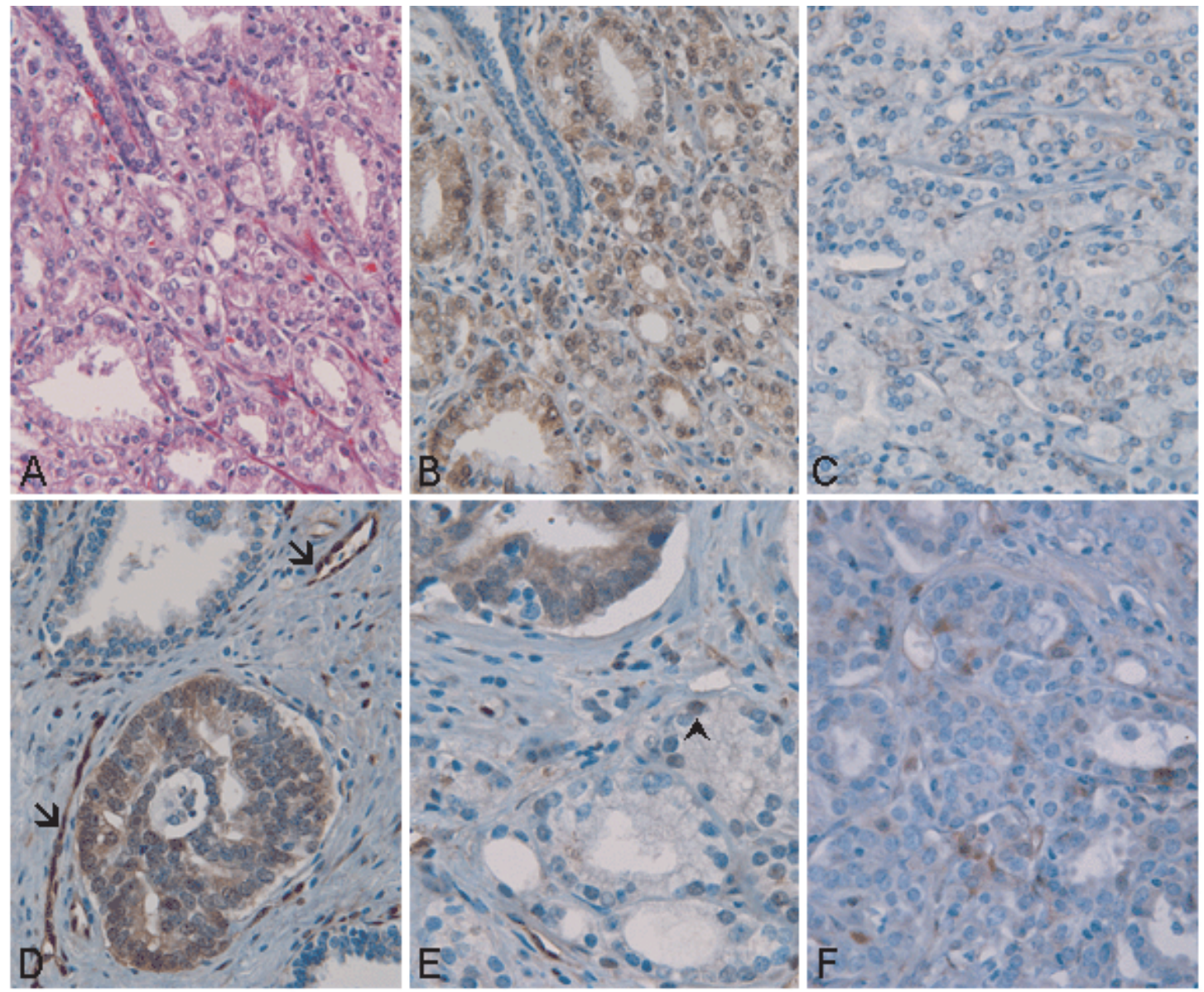

Figure 4 Expression of type $23 \alpha-\mathrm{HSD}$ (AKR1C3) in CaP. (A-C) are taken from Case No. 2. (A) Stained by hematoxylineosin stain. Variation in immunoreactivity in the same tumor is demonstrated by the difference between strong immunoreactivity in (B) and negative immunoreactivity in (C). (D) and (E) From Case No. 1. Note the strong immunoreactivity in the cribiform carcinomatous area in (D) and in endothelial cells (arrow). In (E), there is an abrupt transition from strong immunoreactivity in one neoplastic gland to weak immunoreactivity in other neoplastic gland. Note that the nuclear immunoreactivity is still retained in weakly immunoreactive carcinomatous cells (arrow head). (F) From Case No. 7. There are individual immunoreactive carcinomatous cells admixed with negative carcinomatous cells. Original magnification $\times 60$ in all panels.

demonstrated in the carcinomatous cells (Fig. 4A and B). Variation from strong to negative immunoreactivity was demonstrated within the same tumor (Fig. 4B and C) and also among different tumors (Fig. 4D and E). In Cases No. 1 and No. 9, strong immunoreactivities were predominantly found in cribiform areas that corresponded to a Gleason score of 4, while negative immunoreactivity was found in invasive carcinoma with small glands that corresponded to a Gleason score of 3 (Fig. 4D and E). This pattern of expression was not demonstrated in other tumors that had both cribiform and small gland invasive components. In areas with positive immunoreactivity, it was more often the case to demonstrate positive immunoreactivity in all neoplastic cells within the same gland (Fig. 4B and D). A less common pattern was that individual immunoreactive carcinomatous cells existed within a background of non-immunoreactive carcinomatous cells (Fig. 4F).

\section{Immunoreactivity of AKR1C3 enzyme protein in non-neoplastic conditions}

Focally positive immunoreactivity was also demonstrated in benign glands in areas with chronic inflammation (Fig. 5A). Similar focally positive immunoreactivity was also demonstrated in glands with atrophic changes (Fig. 5B). Positive immunoreactivity 

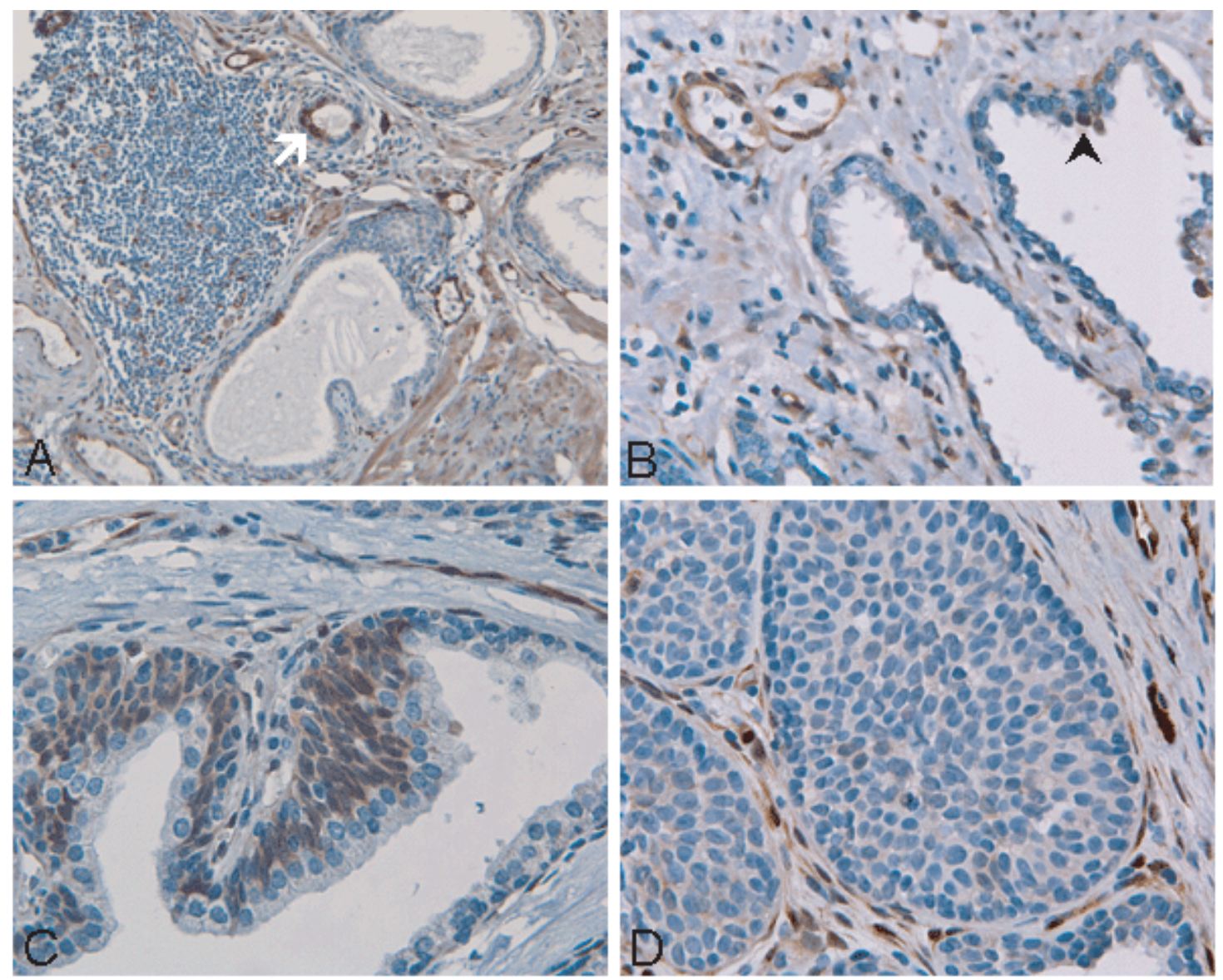

Figure 5 Expression of type $23 \alpha-$ HSD (AKR1C3) in non-neoplastic pathological conditions. (A) An inflamed area where focal increase in immunoreactivity (arrow) is demonstrated. (B) An atrophic area where focal immunoreactivity (arrowhead) is demonstrated. (C) From a prostate gland close to the verumontanum. Cells undergoing urothelial (transitional) cell metaplasia are strongly immunoreactive but prostatic epithelial cells overlying the urothelial (transitional) cell metaplasia are non-immunoreactive. (D) From an area with basal cell hyperplasia which shows negative immunoreactivity. Note the immunoreactivity in stromal and endothelial cells. Original magnification: $(A) \times 20$; $(B-D) \times 60$.

was demonstrated in glandular epithelium with urothelial (transitional) cell metaplasia (Fig. 5C). In contrast, glandular epithelium with basal cell hyperplasia were non-immunoreactive (Fig. 5D).

\section{Relationship between immunoreactivity of AKR1C3 and AR}

IHC staining for AR was performed on sections adjacent to those that had been used for AKR1C3 IHC staining. Both carcinomatous and non-neoplastic prostate gland epithelial cells were immunoreactive for AR. No correlation in staining patterns was observed between AR-positive immunostaining and positive or negative immunoreactivity for AKR1C3 in $\mathrm{CaP}$ (Fig. 6).

\section{Discussion}

An isoform-specific, mouse anti-human mAb (clone NP6G6.A6) that recognizes AKR1C3 but not other members of the AKR1C family has been developed by us (Lin et al. 2004). In this study, we demonstrated that this $\mathrm{mAb}$ can recognize AKR1C3 specifically in total cell lysates obtained from primary cultures of human prostate epithelial cells and human prostate cancer LNCaP cells by western blot analysis. One purpose in the report is to demonstrate that the AKR1C3 $\mathrm{mAb}$ can recognize a single species of protein in human prostate-derived cells. Detection of AKR1C3 transcripts by RT-PCR in these cells showed parallel expression of AKR1C3 mRNA and protein in human prostate cells. 

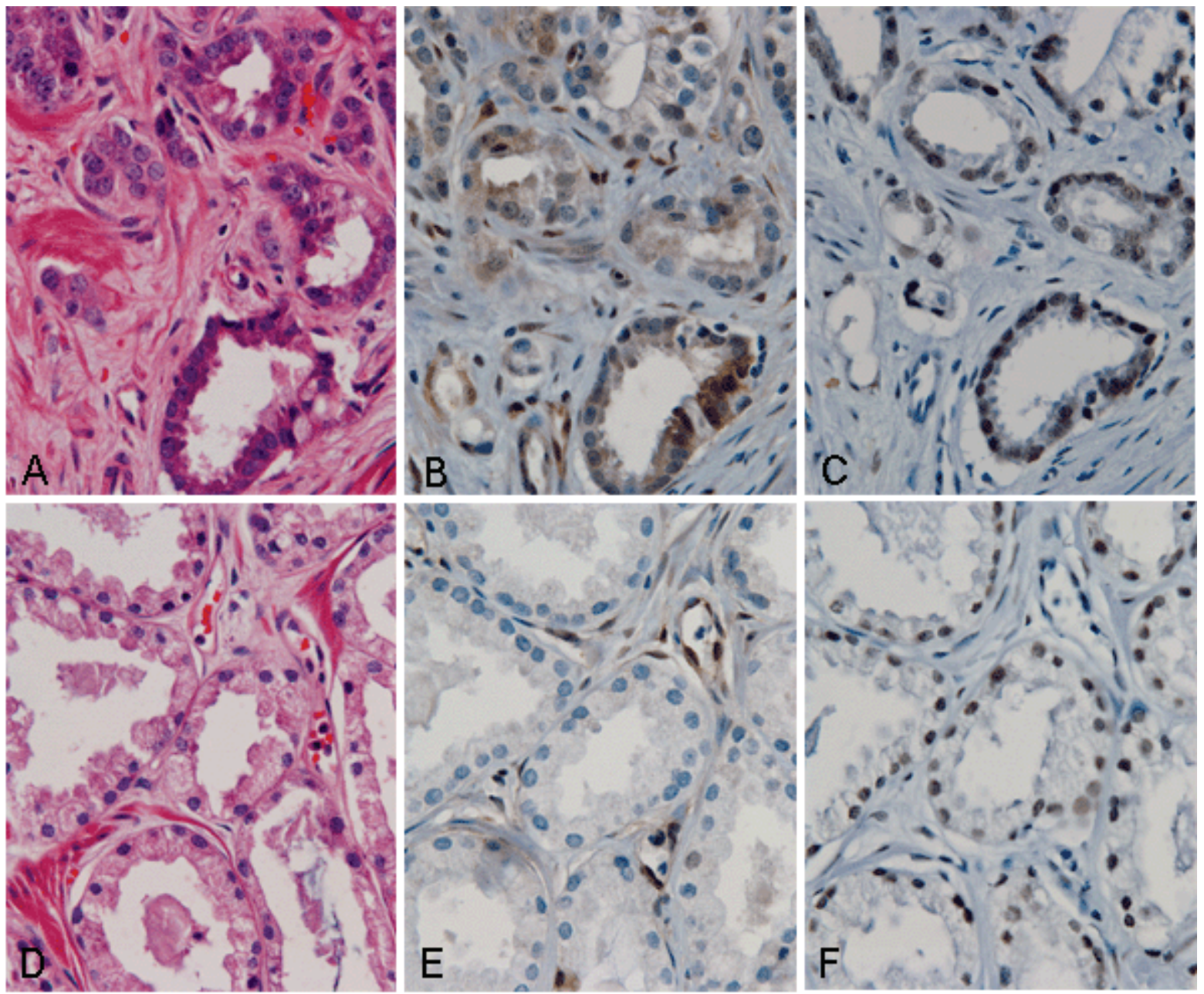

Figure 6 Correlation of AR and AKR1C3 in prostate tissue. All the panels are taken from the carcinoma in Case No. 5. (A-C) Serial sections taken from the one area while (D-F) are taken from a different area. (A) and (D) Hematoxylin-eosin stained, (B) and (E) are IHC for type $23 \alpha$-HSD (AKR1C3), (C) and (F) are IHC for AR. The histopathological features of both areas are comparable as demonstrated in (A) and (D). Immunoreactivity for type $23 \alpha-H S D$ (AKR1C3), however, is positive in one area (B) but negative in another area $(E)$. Nuclear immunoreactivity for $A R$ is demonstrated in both areas $(C$ and $F)$. Original magnification $\times 60$ in all panels.

This antibody was used to study the expression of AKR1C3 in neoplastic and non-neoplastic prostate tissue through IHC. Our results showed cytoplasmic immunoreactivity of AKR1C3 in non-epithelial components of the prostate including endothelial cells, perineurial cells, stromal and smooth muscle cells. Immunoreactivity was also demonstrated in urothelial (transitional) epithelium in the prostatic urethra and also in epithelial cells of seminal vesicles. In contrast, normal prostatic glandular epithelial cells showed only faint or total absence of immunoreactivity with this isoform-specific antibody. Positive cytoplasmic immunoreactivity for AKR1C3 was detected in 9 of $11 \mathrm{CaP}$ cases. We conclude that AKR1C3 is upregulated in $\mathrm{CaP}$. Increased AKR1C3 immunoreactivity in adenocarcinoma cells is in accord with our previous observation that elevated reductive $3 \alpha$-HSD enzymes, such as AKR1C2 (Rizner et al. 2003) and ARK1C3 (Lin et al. 1997) show increased transcript expression in primary cultures of prostate epithelial cells derived from cancerous sections of the prostate.

Surprisingly, we also observed positive nuclear immunoreactivity for AKR1C3. However, this result is consistent with an immunoelectron microscopic study of this enzyme reported by Pelletier et al. (2001), although these authors did not emphasize 
nuclear localization of this enzyme. It is possible that nuclear AKR1C3 performs a yet unknown function. We have ruled out that the nuclear staining is an artifact of antigen retrieval, since the same staining pattern is observed in the presence and absence of antigen retrieval. It is also possible that the nuclear staining is due to the diffusion of AKR1C3 to the nucleus during the sample handling. However, Pelletier observed the nuclear staining following rapid processing of the prostate tissue.

Co-localization of AKR1C3 and AR was also investigated in normal prostate and $\mathrm{CaP}$ specimens. Consistent with previous reports (Chodak et al. 1992, El-Alfy et al. 1999, Labrie et al. 2000b), AR shows a strong nuclei staining pattern. Our data demonstrated that AKR1C3 and AR are co-expressed in the same cell types in prostate tissue, particularly in cases of $\mathrm{CaP}$. However, the increased immunoreactivity of AKR1C3 in CaP cases is not associated with a change in immunoreactivity of $\mathrm{AR}$ as evaluated by IHC. Although there appears to be no correlation between AKR1C3 and AR expression in $\mathrm{CaP}$ using IHC staining, their co-localization in $\mathrm{CaP}$ still supports our hypothesis that AKR1C3 may regulate androgen access to the AR.

Tissue distribution of AKR1C3 has been studied in human reproductive organs including prostate and breast. Using a rabbit polyclonal antibody that was raised against the C-terminal of AKR1C3, El-Alfy et al. (1999) demonstrated positive immunoreactivity in stromal and endothelial cells in the prostate. A similar pattern of positive immunoreactivity in prostate stromal and endothelial cells was observed in our study. However, El-Alfy et al. demonstrated positive immunoreactivity in the glandular basal cells but not the luminal epithelial cells. In our study, however, most of the luminal and basal epithelial cells of prostatic glands were negative or, at most, faintly immunoreactivity. The causes of discrepancies between these two studies are not clear. It may reflect difference in the cross-reactivity of the two antibodies. Our mAb is specific for AKR1C3, while the polyclonal antibody for AKR1C3 may cross-react with AKR1C1, which is expressed in the prostate (D M Bauman and $\mathrm{T} M$ Penning, unpublished observations).

Multiple hypotheses exist to explain the elevated AKR1C3 expression in $\mathrm{CaP}$ and a role of this enzyme in the pathogenesis of CaP. First, with its type $517 \beta$ HSD activity, AKR1C3 can generate the local source of potent androgen by converting $\Delta^{4}$-dione to testosterone (Labrie et al. 2000a). The subsequent intraprostatic accumulation of testosterone can serve as substrate for type $25 \alpha$-reductase, enhance AR trans-activation activity, and act as a growth advantage for the adenocarcinoma even in the absence of elevated AR protein expression.

Secondly, based on our previous observation that $3 \alpha$-diol can stimulate prostate cell proliferation through an AR-independent, growth factor-like pathway(s) in vitro (Nunlist et al. 2004, Zimmerman et al. 2004), it is possible that AKR1C3 converts the potent androgen, 5 $\alpha$-DHT, into its cognate metabolite, $3 \alpha$-diol, and regulates the utilization of AR or growth factor receptor signaling pathways in the prostate. Growing evidence suggests $3 \alpha$-diol might be an important hormone with its own androgenic effects in hormone target organs through yet undefined pathway(s). It has been suggested that $3 \alpha$-diol is a more potent androgen than $5 \alpha$-DHT or testosterone in inducing prostatic hyperplasia in the castrated dog (Walsh \& Wilson 1976, Jacobi et al. 1978) and may be more effective than $5 \alpha$-DHT in virilizing the urogenital tract including prostate both in the fetal rat (Schultz \& Wilson 1974) and in the fetus of the pouch of female marsupials (Wilson et al. 2003a,b, Leihy et al. 2004).

Thirdly, via its 11-ketoprostaglandin reductase activity, AKR1C3 catalyzes the 11-keto-reduction of $\mathrm{PGD}_{2}$ to yield the $\mathrm{PGF}_{2 \alpha}$ epimer, $9 \alpha, 11 \beta-\mathrm{PGF}_{2}$ (Desmond et al. 2003). This enzymatic function causes AKR1C3 to divert $\mathrm{PGD}_{2}$ catabolism to $9 \alpha, 11 \beta-\mathrm{PGF}_{2 \alpha}$ and reduce the accumulation of $\mathrm{PGJ}_{2}$, a ligand for PPAR $\gamma$ receptor (Desmond et al. 2003). A functional consequence of $\mathrm{PGJ}_{2}$ deprivation is that the growth inhibitory effects of $15 \Delta \mathrm{PGJ}_{2}$ in $\mathrm{CaP}$ are attenuated (Subbarayan et al. 2004). This also prevents the downregulation of COX-2, which when elevated can have a pronounced effect on microvessel density and angiogenesis in prostatic tumors (Kirschenbaum et al. 2001, Sabichi et al. 2004). $\mathrm{PGD}_{2}$-induced cell proliferation and $\mathrm{PGJ}_{2}$-induced differentiation and programmed cell death have been identified in variety of cell types including prostate cancer cells (Butler et al. 2000, Desmond et al. 2003, Yee et al. 2003, Morosetti et al. 2004, Zang et al. 2004). Furthermore, the activation of PPAR $\gamma$ by a synthetic ligand, troglitazone, suppressed AR trans-activation activity in prostate cancer cells and serum prostate-specific antigen levels in a patient with $\mathrm{CaP}$ (Hisatake et al. 2000). Therefore, elevated expression of AKR1C3 may regulate $\mathrm{PG}$ metabolism in the prostate and cause the accumulation of the proliferative PG, $9 \alpha, 11 \beta-\mathrm{PGF}_{2 \alpha}$. AKR1C3 may also be intimately involved in controlling proliferative growth and vascular development in the diseased prostate through this pathway. We are actively studying the relationship between AKR1C3 and PPAR $\gamma$ expression in CaP. 
In our study, elevated AKR1C3 immunoreactivity was also detected in non-neoplastic conditions including chronic inflammation, atrophic changes and urothelial (transitional) cell metaplasia. Lipid metabolism including arachidonic acid and PG has been implicated in these disorders (Heller et al. 1998). Furthermore, involvement of PPAR $\gamma$ has been reported in regulating lipid homeostasis, immune response, cell differentiation and cell proliferation (Heller et al. 1998, Bishop-Bailey \& Wray 2003, Varley et al. 2004). We conclude that upregulation of AKR1C3 as reflected by an increase in immunoreactivity is associated with both neoplastic and nonneoplastic pathological changes in the prostate.

$\mathrm{CaP}$ has been recognized as heterogeneous, multifocal cancer that can be induced by multiple carcinogenic factors. In this study, elevated expression of AKR1C3 protein has been demonstrated in the epithelium of the majority of $\mathrm{CaP}$ as well as in nonneoplastic processes such as inflammation. As AKR1C3 regulates steroid hormone and PG metabolism in endocrine target tissues, expression of AKR1C3 in $\mathrm{CaP}$ implicates a possible role in tumorigenesis of $\mathrm{CaP}$. This possible mechanism awaits elucidation.

\section{Acknowledgements}

This work was supported in part by NIH grants DK47015 and CA97044 (to TMP) and DK54925 (to H K L). The authors declare that there is no conflict of interest that would prejudice the impartiality of this scientific work.

\section{References}

Bishop-Bailey D \& Wray J 2003 Peroxisome proliferatoractivated receptors: a critical review on endogenous pathways for ligand generation. Prostaglandins and other Lipid Mediators 71 1-22.

Butler R, Mitchell SH, Tindall DJ \& Young CY 2000 Nonapoptotic cell death associated with S-phase arrest of prostate cancer cells via the peroxisome proliferatoractivated receptor $\gamma$ ligand, 15-deoxy- $\Delta^{12,14}$-prostaglandin $\mathbf{J}_{2}$. Cell Growth and Differentiation 11 49-61.

Chodak GW, Kranc DM, Puy LA, Takeda H, Johnson K \& Chang C 1992 Nuclear localization of androgen receptor in heterogeneous samples of normal, hyperplastic and neoplastic human prostate. Journal of Urology 147 798-803.

Desmond JC, Mountford JC, Drayson MT, Walker EA, Hewison M, Ride JP, Luong QT, Hayden RE, Vanin EF \& Bunce CM 2003 The aldo-keto reductase AKR1C3 is a novel suppressor of cell differentiation that provides a plausible target for the non-cyclooxygenase-dependent antineoplastic actions of nonsteroidal anti-inflammatory drugs. Cancer Research 63 505-512.

Dufort I, Soucy P, Labrie F \& Luu-The V 1996 Molecular cloning of human type $33 \alpha$-hydroxysteroid dehydrogenase that differs from $20 \alpha$-hydroxysteroid dehydrogenase by seven amino acids. Biochemical and Biophysical Research Communications 228 474-479.

El-Alfy M, Luu-The V, Huang X-F, Berger L, Labrie F \& Pelletier G 1999 Localization of type 5 17 hydroxysteroid dehydrogenase, $3 \beta$-hydroxysteroid dehydrogenase, and androgen receptor in the human prostate by in situ hybridization and immunocytochemistry. Endocrinology 140 1481-1491.

Fung KM, Lee VM \& Trojanowski JQ 1995 Dynamics of cell proliferation and cell death during the emergence of primitive neuroectodermal tumors of the immature central nervous system in transgenic mice. American Journal of Pathology 146 1376-1387.

Heller A, Koch T, Schmeck J \& van Ackern K 1998 Lipid mediators in inflammatory disorders. Drugs 55 487-496.

Hisatake JI, Ikezoe T, Carey M, Holden S, Tomoyasu S \& Koeffler HP 2000 Down-regulation of prostate-specific antigen expression by ligands for peroxisome proliferatoractivated receptor $\gamma$ in human prostate cancer. Cancer Research 60 5494-5498.

Isaacs JT, Furuya Y \& Berges R 1994 The role of androgen in the regulation of programmed cell death/apoptosis in normal and malignant prostatic tissue. Seminars in Cancer Biology 5 391-400.

Jacobi GH, Moore RJ \& Wilson JD 1978 Studies on the mechanism of $3 \alpha$-androstanediol-induced growth of the dog prostate. Endocrinology 102 1748-1755.

Kim J, Yang P, Suraokar M, Sabichi AL, Llansa ND, Mendoza G, Subbarayan V, Logothetis CJ, Newman RA, Lippman SM et al. 2005 Suppression of prostate tumor cell growth by stromal cell prostaglandin D synthasederived products. Cancer Research 65 6189-6198.

Kirschenbaum A, Liu X, Yao S \& Levine AC 2001 The role of cyclooxygenase-2 in prostate cancer. Urology 58 127-131.

Labrie F, Luu-The V, Lin SX, Simard J, Labrie C, El-Alfy M, Pelletier G \& Belanger A 2000a Intracrinology: role of the family of $17 \beta$-hydroxysteroid dehydrogenases in human physiology and disease. Journal of Molecular Endocrinology 25 1-16.

Labrie F, Luu-The V, Lin SX, Simard J \& Labrie C $2000 b$ Role of $17 \beta$-hydroxysteroid dehydrogenases in sex steroid formation in peripheral intracrine tissues. Trends in Endocrinology and Metabolism 11 421-427.

Lang SH, Stark M, Collins A, Paul AB, Stower MJ \& Maitland NJ 2001 Experimental prostate epithelial morphogenesis in response to stroma and threedimensional matrigel culture. Cell Growth and Differentiation 12 631-640.

Leihy MW, Shaw G, Wilson JD \& Renfree MB 2004 Penile development is initiated in the tammar wallaby pouch young during the period when 
$5 \alpha$-androstane- $3 \alpha, 17 \beta$-diol is secreted by the testes. Endocrinology 145 3346-3352.

Lin H-K, Jez JM, Schlegel BP, Peehl DM, Pachter JA \& Penning TM 1997 Expression and characterization of recombinant type $23 \alpha$-hydroxysteroid dehydrogenase (HSD) from human prostate: demonstration of bifunctional $3 \alpha / 17 \beta-H S D$ activity and cellular distribution. Molecular Endocrinology 11 1971-1984.

Lin H-K, Steckelbroeck S, Fung K-M, Jones AN \& Penning TM 2004 Characterization of a monoclonal antibody for human aldo-keto reductase AKR1C3 (type 2 $3 \alpha$-hydroxysteroid dehydrogenase/type $517 \beta$ hydroxysteroid dehydrogenase); immunohistochemical detection in breast and prostate. Steroids 69 795-801.

Mahendroo MS, Cala KM \& Russell DW 1996 5o-reduced androgens play a key role in murine parturition. Molecular Endocrinology 10 380-392.

Matsuura K, Shiraishi H, Hara A, Sato K, Deyashiki Y, Ninomiya M \& Sakai S 1998 Identification of a principal mRNA species for human $3 \alpha$-hydroxysteroid dehydrogenase isoform (AKR1C3) that exhibits high prostaglandin $\mathrm{D}_{2}$ 11-ketoreductase activity. Journal of Biochemistry 124 940-946.

Morosetti R, Servidei T, Mirabella M, Rutella S, Mangiola A, Maira G, Mastrangelo R \& Koeffler HP 2004 The PPAR $\gamma$ ligands $\mathrm{PGJ}_{2}$ and rosiglitazone show a differential ability to inhibit proliferation and to induce apoptosis and differentiation of human glioblastoma cell lines. International Journal of Oncology 25 493-502.

Nunlist EH, Dozmorov I, Tang Y, Cowan R, Centola M \& Lin H-K 2004 Partitioning of $5 \alpha$-dihydrotestosterone and $5 \alpha$-androstane- $3 \alpha, 17 \beta$-diol activated pathways for stimulating human prostate cancer LNCaP cell proliferation. Journal of Steroid Biochemistry and Molecular Biology 91 157-170.

Pelletier G, Luu-The V, Tetu B \& Labrie F 1999 Immunocytochemical localization of type $517 \beta$ hydroxysteroid dehydrogenase in human reproductive tissues. Journal of Histochemistry and Cytochemistry $\mathbf{4 7}$ 731-737.

Pelletier G, Luu-The V, El-Alfy M, Li S \& Labrie F 2001 Immunoelectron microscopic localization of $3 \beta$-hydroxysteroid dehydrogenase and type 5 $17 \beta$-hydroxysteroid dehydrogenase in the human prostate and mammary gland. Journal of Molecular Endocrinology 26 11-19.

Penning TM, Burczynski ME, Jez JM, Hung CF, Lin HK, Ma H, Moore M, Palackal N \& Ratnam K 2000 Human $3 \alpha$-hydroxysteroid dehydrogenase isoforms (AKR1C1AKR1C4) of the aldo-keto reductase superfamily: functional plasticity and tissue distribution reveals roles in the inactivation and formation of male and female sex hormones. Biochemical Journal 351 67-77.

Penning TM, Burczynski ME, Jez JM, Lin HK, Ma H, Moore M, Ratnam K \& Palackal N 2001 Structurefunction aspects and inhibitor design of type 5 17ß-hydroxysteroid dehydrogenase (AKR1C3). Molecular and Cellular Endocrinology 171 137-149.

Rizner TL, Lin HK, Peehl DM, Steckelbroeck S, Bauman DR \& Penning TM 2003 Human type 3 $3 \alpha$-hydroxysteroid dehydrogenase (aldo-keto reductase $1 \mathrm{C} 2$ ) and androgen metabolism in prostate cells. Endocrinology 144 2922-2932.

Sabichi AL, Subbarayan V, Llansa N, Lippman SM \& Menter DG 2004 Peroxisome proliferator-activated receptor- $\gamma$ suppresses cyclooxygenase- 2 expression in human prostate cells. Cancer Epidemiology, Biomarkers and Prevention 13 1704-1709.

Schultz FM \& Wilson JD 1974 Virilization of the Wolffian duct in the rat fetus by various androgens. Endocrinology 94 979-986.

Subbarayan V, Sabichi AL, Kim J, Llansa N, Logothetis CJ, Lippman SM \& Menter DG 2004 Differential peroxisome proliferator-activated receptor- $\gamma$ isoform expression and agonist effects in normal and malignant prostate cells. Cancer Epidemiology, Biomarkers and Prevention 13 1710-1716.

Varley CL, Stahlschmidt J, Smith B, Stower M \& Southgate J 2004 Activation of peroxisome proliferator-activated receptor-gamma reverses squamous metaplasia and induces transitional differentiation in normal human urothelial cells. American Journal of Pathology 164 1789-1798.

Walsh PC \& Wilson JD 1976 The induction of prostatic hypertrophy in the dog with androstanediol. Journal of Clinical Investigation 57 1093-1097.

Wilson JD, Auchus RJ, Leihy MW, Guryev OL, Estabrook RW, Osborn SM, Shaw G \& Renfree MB $2003 a$ $5 \alpha$-androstane- $3 \alpha, 17 \beta$-diol is formed in tammar wallaby pouch young testes by a pathway involving $5 \alpha$-pregnane$3 \alpha, 17 \alpha$-diol-20-one as a key intermediate. Endocrinology $144575-580$.

Wilson JD, Leihy MW, Shaw G \& Renfree MB $2003 b$ Unsolved problems in male physiology: studies in a marsupial. Molecular and Cellular Endocrinology 211 33-36.

Yee LD, Guo Y, Bradbury J, Suster S, Clinton SK \& Seewaldt VL 2003 The antiproliferative effects of PPAR $\gamma$ ligands in normal human mammary epithelial cells. Breast Cancer Research and Treatment 78 179-192.

Zang C, Liu H, Posch MG, Waechter M, Facklam M, Fenner MH, Ruthardt M, Possinger K, Phillip Koeffler H \& Elstner E 2004 Peroxisome proliferator-activated receptor gamma ligands induce growth inhibition and apoptosis of human B lymphocytic leukemia. Leukemia Research 28 387-397.

Zimmerman RA, Dozmorov I, Nunlist EH, Tang Y, Li X, Cowan R, Centola M, Frank MB, Culkin DJ \& Lin H-K $20045 \alpha$-Androstane-3 $\alpha, 17 \beta$-diol activates a pathway that resembles the epidermal growth factor responsive pathways in stimulating human prostate cancer LNCaP cell proliferation. Prostate Cancer and Prostatic Diseases 7 364-374. 